\title{
小児および成人の慢性副鼻腔炎に対する保存的治療
}

—エリスロマイシン及びその誘導体の効果——

$\begin{array}{ccccccc}\text { 広島大学耳鼻咽喉科 } & & & & \\ \text { 夜 } & \text { 陣 } & \text { 紘 } & \text { 治 } & \text { 小 } & \text { 野 } & \text { 邦 彦 } \\ \text { 益 田 } & & \text { 慎 } & \text { 平 川 } & \text { 勝 } & \text { 洋 } \\ \text { 県立安芸津病院 } & & & & & & \\ \text { 串 田 } & \text { 伸 } & & & & & \end{array}$

\section{Clinical effects of erythromycin derivatives on patients with chronic paranasal sinusitis.}

\author{
Koji Yajin, Kunihiko Ono, Shin Masuda, Katsuhiro Hirakawa \\ and Shin-ichi Kushida*
}

Department of Otorhinolaryngology, School of medicine Hiroshima University, Hiroshima

Department of Otorhinolaryngology, Hiroshima prefectural Akitsu Hospital, Akitsu*

We investigated the clinical effects of long term therapy of the Erythromycin derivatives, Erythromycin (EM), Clarithromycin (CAM) and Roxithromycin (RXM), for chronic paranasal sinusitis. Seventy-one children (younger than 15 years old) and 87 adults (older than 16) were divided in 2 groups based on the presence or absence of nasal allergy.

The patients without nasal allergy were divided into the following 3 groups; group-A was treated with EM derivative alone, group-B with EM derivative and S-carboxyl methyl cystein (SCMC) and grourp-C with SCMC alone. Patients with nasal allergy were treated with anti-allergic agent and EM derivative (goup-D) or with EM derivative only (group-E).

Each EM derivative was administered at half the level of the normal doses and each antiallergic agent was given at the normal doses every day for 12 weeks.

The following results were obtained;

1) The improvement rates of symptoms and rhinoscopic findings were $60 \%$ (group-A) and $75 \%$ (group-B) in children and $60 \%$ (group-A) and $52.9 \%$ (group-B) in adults respectively. No significant difference in clinical effects was observed between children and adults in groups A and B.

2) In group-E, improvement rates were $44.4 \%$ in children and $100 \%$ in adults, a result that showed significant difference.

In 26 children with chronic sinusitis intermittently treated by the administration of EM or CAM for more than 2 years, 5 (63\%) out of 8 patients with no nasal allergy showed improvement of symptoms after 4 month-treatment. 
While improvement was observed in 15 (83\%) out of 18 patients with nasal allergy after 8 monthtreatment.

No remarkable side effects were noted in any group.

Key words：慢性副鼻腔炎, 小児, 成人, 14 員環系マクロライド

\section{はじめに}

近年, 小児の慢性副鼻腔炎は昭和 40 年以前の有病率 に比して激減しているといわれるが, 我々 ${ }^{122}$ の学童, 生徒の学校検診結果によれば 15 年前と本年の有病率 は $2.8 \%$ と $3.2 \%$ であり，ここ 15 年間は横這い状態で ある。一方高齢化社会といわれる今日, 60 歳以上の高 齢者の慢性副鼻腔炎の外来患者に占める率も，飯沼 ${ }^{3)}$ によれば必ずしも上昇しているとはいえないが，約 $2 \%$ あるると報告している。すなわち，慢性副鼻腔炎 は減少したとはいえ, 依然として我々耳鼻科医の重要 な対象疾患のひとつである。

慢性副鼻腔炎に対する治療は保存的治療から手術的 治療まで種々あるが, 近年, 14 員環系マクロライド(以 下，マクロライドと略す）の少量長期投与による有効 性を認める報告(5)56) が多くなされている。しかし，小 児と成人の慢性副鼻腔炎に対するマクロライドの効果 の比較や投与期間の検討は未だ多いとはいえない。 我々はこの点に関して検討を試み, 若干の知見を得た ので報告する。

\section{対象および方法}

\section{1. 対 象}

広島大学医学部附属病院耳鼻咽喉科㧍よび関連施設 を初診した小児（4〜15 歳）と成人（16 歳以上）で問 診および諸検査（自覚症状, 他覚所見, サッカリンテ スト, X線検查, 鼻汁中好中球数・好酸球数, アレル ゲン皮内反応検査，RAST）を行って，慢性副鼻腔炎 と診断した症例を対象とした。但し，治療開始前 2 週 間に急性増悪を認めた症例や，手術的治療の既往のあ る症例は除外した。鼻汁中好酸球数，アレルゲン皮内 反応検查, RAST の内, 2 つ以上の検査で陽性を示し たものをアレルギー性鼻炎合併例（以下，鼻ア合併例 と略す）とし，陰性の場合は慢性副鼻腔炎単独例（以 下，単独例と略す) として，表 1 に示す如く，単独例 には 3 組の投与方法, 鼻ア合併例には 2 組の投与方法 の組み合わせで比較検討した。

2. 投与薬剤および方法
表 1 投与薬剤の組み合わせ

慢性副鼻腔炎単独例
$\mathrm{A}$ 群 ： マクロライドのみ
$\mathrm{B}$ 群 ： マクロライド+ S CMC
$\mathrm{C}$ 群 : $\mathrm{SCMCのみ}$

アレルギ一性鼻炎合併例

$\mathrm{D}$ 群 : 抗アレルギー剤のみ

E 群 ： マクロライド十抗アレルギー剤

投与するマクロライドは成人にはエリスロマイシン (EM)，ロキシスロマイシン $(\mathrm{RXM})$, クラリスロマイ シン（CAM）の内のいずれかを常用量の $1 / 2$ ，すなわ ち, EM は 400〜 600mg/日, RXM は 150mg/日, CAM は 200mg/日とし，小児にはCAM50mg/日または $\mathrm{EM} 200 \sim 300 \mathrm{mg} /$ 日のいずれかを投与することとし た。

単独例に対しては, A群：マクロライド単独投与, B 群：マクロライド $+\mathrm{S}$ 一カルボキシメチルシステイ ン・SCMC（成人には 1 日 6 錠，小児には $30 \mathrm{mg} / \mathrm{kg}$ を 投与) の併用投与, $\mathrm{C}$ 群: SCMC 単独投与の 3 群の投 与方法とした。

一方, 鼻ア合併例に対しては, $\mathrm{D}$ 群：抗アレルギー 剤単独投与, $\mathrm{E}$ 群：マクロライド十抗アレルギー剤の 併用投与の 2 群の投与方法に分けて薬剂の効果を比較 した。

抗アレルギー剤は小児扔よび成人に適応のある薬剤 を選択することとし，常用量を投与することとした。 但し，マクロライドとの併用が禁忌とされている薬剤 は投与しないこととした。

各投与群の決定は, 単独例, 鼻乃合併例いずれもで きるだけ無作為に投与することとした。投与期間は最 短 12 週間とした。

点鼻薬や他の薬剤は併用しないこととし，鼻処置， ネブライザー療法は 2 週間に一度，来院時に必要なら 行うこととした。

3. 臨床症状の評価 
表 2 評価する自覚症状と他覚所見

自賞症状

\begin{tabular}{|c|c|c|c|c|}
\hline 鼻汁量 & （0.なし & 1. 少量 & 2. 中等量 & 3.多量) \\
\hline 後舅漏 & （0.なし & 1. 時々ある & 2.よくある & 3. 常にある) \\
\hline 鼻 閉 & (0.なし & 1.舅閉を感じるが口呼吸はない & 2. 時々口呼吸 & 3. 常に口呼吸） \\
\hline 頭重・頭痛 & (0.なし & 1. 時々ある & 2.よくある & 3.常にある) \\
\hline 嗅覚障害 & （0.なし & 1.ほぼ正常 & 2.少し具いがある & 3.全く真わない) \\
\hline くしゃみ & (0.0 回 & 1. 4 回以下 & 2. 5 回 9回 & 3.10 回以上) \\
\hline
\end{tabular}

他 賞 所見
舅ポリープ（0.なし
1. 中畕道にわずか
2. 中舅道に充満
3. 鼻内に充満）
甲介粘膜腫脹 $(0$ 。な
1. 中甲介中央まで見える
2. 中甲介はなんとか見える
3. 中甲介見えず)
舅汁性状
（０、整液性またはなし
1 . 粘性
2. 粘膿性
3. 膿性)
後䔬漏 $(0 . な し$
1 . 軽度
2. 中等度
3. 多量)

評価する自覚症状, 他覚所見は表 2 の如く, それぞ れ 4 段階に分類して, 投与前, 投与後 2 週目, 4 週目, 6 週目, 8 週目, 10 週目, 12 週目に評価した。

諸家 ${ }^{5) 7)}$ の判定法に従って, 上記各自覚症状, 他覚所 見の項目毎の変化を下記の基準に従って効果判定し た。

著効: $3 \rightarrow 0,2 \rightarrow 0$, 有効: $3 \rightarrow 1,1 \rightarrow 0$, や有効: $3 \rightarrow 2,2 \rightarrow 1$, 無効: 変化のないもの, 悪 化: 投与後, 数值が上昇したもの。

効果判定後, 各判定項目に著効 4 点, 有効 3 点, や や有効 2 点, 無効 1 点, 悪化 -5 点を与え, 自覚症状, 他覚所見の効果判定得点 $\mathrm{X}$ (=各項目の点数の総和： 項目数）を求めた。

自覚症状, 他覚所見の効果判定は $\mathrm{X} \geqq 3$ : 著効, $2<$ $\mathrm{X}<3$ : 有効, $1<\mathrm{X} \leqq 2$ : やや有効, $0<\mathrm{X} \leqq 1$ : 無 効, $\mathrm{X} \leqq 0$ : 悪化とした。

得られた自覚症状, 他覚所見の判定結果を図 1 の基

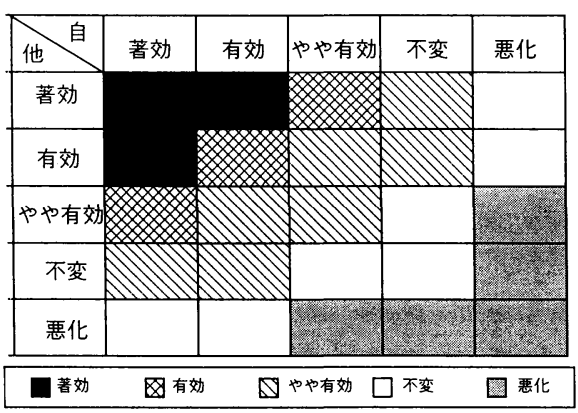

図 1 総合効果判定基準
準に従って総合的に効果判定した。

4. X線所見の効果判定

ウオータース法, 後頭前頭法または冠状断 CT によ り, 治療前後の上頻洞, 篩骨洞の陰影の状態を 4 段階 (3: 完全陰影, 2：1 と 3 の中間, 1 : 軽度の部分陰影, 0 : 陰影なし)に評価した。さらに治療前後のX線所見 を以下の基準により効果判定を行った。

各洞の判定区分は, 著明改善: $3 \rightarrow 0,2 \rightarrow 0$, 改 善: $3 \rightarrow 1,1 \rightarrow 0$, 軽度改善: $3 \rightarrow 2,2 \rightarrow 1$, 不 変: 変化のないもの, 悪化: 投与後, 数值が上昇した ものとした。

得られた上顎洞と篩骨洞の各々の陰影の改善状態を 図 1 と同様の方法で総合的に効果判定を行い, 著明改 善, 改善, 軽度改善, 不変, 悪化とした。改善率は(著 明改善十改善) $\div$ 症例数 $\times 100$ とした。

\section{背景因子の分析}

平均罹病期間は小児で 10 力月, 成人で 43 力月で あった。

総症例数は表 3 の如く 158 例で, この内, 小児 71 名, 成人 87 名であった。副鼻腔炎単独例は小児で 34 名, 成人で 65 名であり, 鼻ア合併例は小児で 37 名 (52.1\%)，成人で 22 名 $(25.3 \%)$ であった。また， 12 週まで各薬剤を投与できた症例数は表 3 の（）に示す 如くで, 薬剤の効果の比較についてはこの症例数で検 討した。

年齢構成は図 2 に示す如くである。

初診時自覚症状, 他覚所見の有症状率, 有所見率は 
表 3 総症例数

\begin{tabular}{|c|c|c|}
\hline & 小 児 & 成 人 \\
\hline 副鼻腔炎単 独 例 & 34名 (25) & 65名 (53) \\
\hline アレルギー鼻炎合併例 & 37名 (22) & 22名 ( 8) \\
\hline 計 & 71 名 (47) & 87 名 (61) \\
\hline
\end{tabular}

（）は薬剤を12週間投与できた症例数

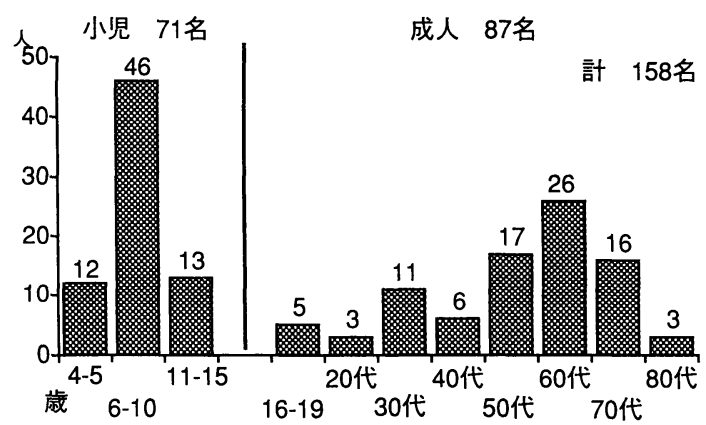

図 2 年齢分布

表 4 初診時の自覚症状と他覚所見

自覚症状

\begin{tabular}{|c|c|c|}
\hline & 小 & 成 \\
\hline 汁 & 68名（95.8\%） & 83名 (95.4\%) \\
\hline 後 鼻 漏 & 45名（63.4\%） & 78名 (89.7\%) \\
\hline 鼻 & 59 名 $(83.1 \%)$ & 76名 (87.3\%) \\
\hline 頭重 - 頭痛 & 15名 (21.1\%) & 47名（54.0\%） \\
\hline 嗅 覚 障 害 & 6名 ( $8.5 \%)$ & 39名（44.9\%) \\
\hline
\end{tabular}

他覚所見

\begin{tabular}{|c|c|c|}
\hline & 小 & 成 \\
\hline 鼻 & 2名 ( $2.8 \%)$ & 24名（27.6\%） \\
\hline 甲介粘膜腫脹 & 62名 (87.3\%) & 73名 (83.9\%) \\
\hline 鼻 & 67名 (94.4\%) & 83名 $(95.4 \%)$ \\
\hline 後 鼻 漏 & 49名（69.0\%） & 68名 $(78.2 \%)$ \\
\hline
\end{tabular}

表 4 に示した。小児の自覚症状において嗅覚障害, 頭 重・頭痛が少なく,他覚所見で鼻茸を認める率が低かっ

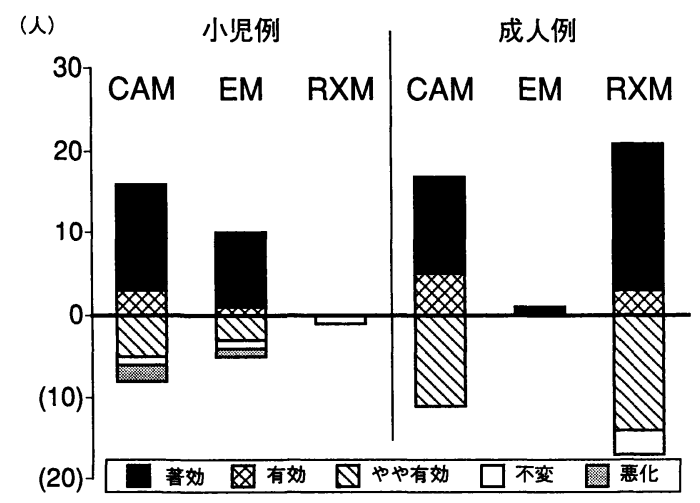

図 3 投与したマクロライド別の総合効果

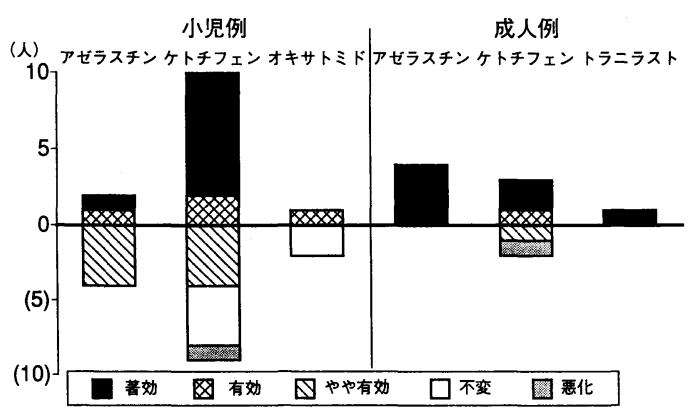

図 4 投与した抗アレルギー郕別の総合効果

たが，その他の症状，所見では，小児，成人に差は認 めなかった。

図 $3 ， 4$ は，投与したマクロライドおよび抗アレル ギー剂の効果を示したものであるが，小児，成人いず れも, どの薬剤の有効率にも有意差は認めなかった。

ここで有効率とは $($ 著効例 + 有効例 $) \div$ 全症例 $\times 100$ と した。

投与群別の症例数は表 5 に示す如くであるが，成人 の鼻ア合併例に対する抗アレルギー剤のみの投与の D 群は該当例がなかった。

\section{結果}

1. 自覚症状に対する効果（図 5 )

自覚症状に関しては，いずれの症状も小児と成人に おいて有効率に有意差はなく, 同程度の効果がみられ た。

2. 他覚所見に対する効果（図 6 ）

他覚所見に関しても鼻茸を除けば，いずれも小児と 
表 5 群別症例数

\begin{tabular}{|c|c|c|}
\hline & 小 览 & 成 人 \\
\hline A & 11名 ( 5) & 13名 $(10)$ \\
\hline B & 29名 $(20)$ & 54名 $(34)$ \\
\hline C & 3名 (0) & 10名 $(9)$ \\
\hline D & 7名 $(4)$ & 0名 $(0)$ \\
\hline E & 21名 (18) & 10名 $(8)$ \\
\hline 総 計 & 71名 $(47)$ & 87名 $(61)$ \\
\hline
\end{tabular}

（）は薬剤を12週間投与できた症例数

小児

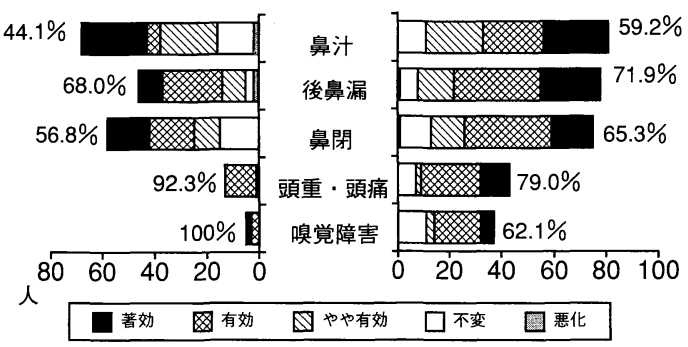

図 5 自覚症状の有効率

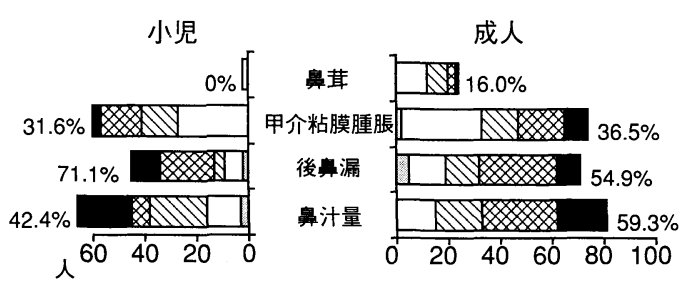

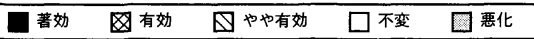

図 6 他覚所見の有効率

成人で有意差は認められなかった。鼻茸に関しては成 人では 1 例ではあるが著効を示し, 有効率は $16 \%$ で あったが,小児では明らかな効果は認められなかった。

3. X線所見の改善率

小児の単独例での改善率は $42 \%$, 鼻ア合併例で $50 \%$ であった。一方, 成人の単独例では $21 \%$, 鼻ア合併例 で $80 \%$ の改善率であった。

4. 単独例に対する効果

イ。 小児に対する効果（図 7)
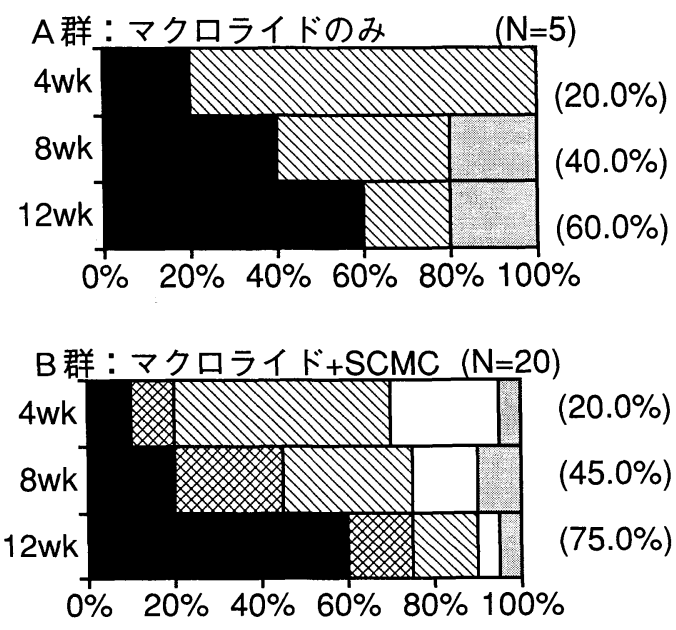

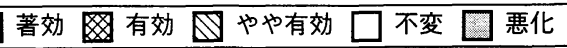

図 7 小肾の慢性副鼻腔炎 単独例に対する有効率

小児では 12 週間 SCMC のみを投与したC 群症例が なかったのでA群と B 群での比較をした。

A 群では, 有効率は 4 週で $20 \%, 8$ 週で $40 \%$ と週を 追う毎に高くなり，12 週では $60 \%$ の有効率であった。

B群でも，A群と同様に週を追う毎に有効率は高く なり, 12 週投与時では $75 \%$ の有効率であった。A群に 比して有効率は高かったが, 有意差は認めなかった。

口。成人に対する効果（図 8)

成人でも，A群，B群ともに小坚と同様に週を追う 毎に有効率は高くなり, A群では 12 週では $60 \%, \mathrm{~B}$ 群 では $52.9 \%$, C 群では $44.4 \%$ であったが 3 群いずれに も有意差は認めなかった。SCMC 単独投与でも著効例 がみられたことは注目されるが,逆に 12 週でも不変例 がなおみられることは，A，B群で不変例がみられな くなるのとは対称的であった。

5. 鼻ア合併例に対する効果

イ。 小児に対する効果（図 9)

抗アレルギー剤のみを投与した D群では， 4 週， 8 週では $25 \%, 0 \%$ と有効率は大変低いが， 12 週投与に より，50\%の有効率を示した。

一方，マクロライドとの併用投与による $\mathrm{E}$ 群でも 4 週， 8 週の有効率は低く，12 週の有効率は $44.4 \%$ で あった。 $\mathrm{D}, \mathrm{E}$ 群の 12 週での有効率に有意差は認めな かった。 
A 群：マクロライドのみ

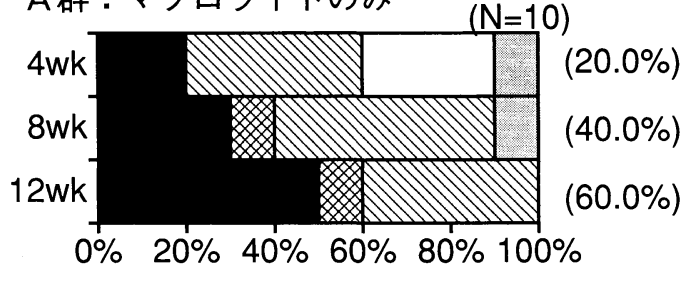

B 群 : マクロライド+SCMC

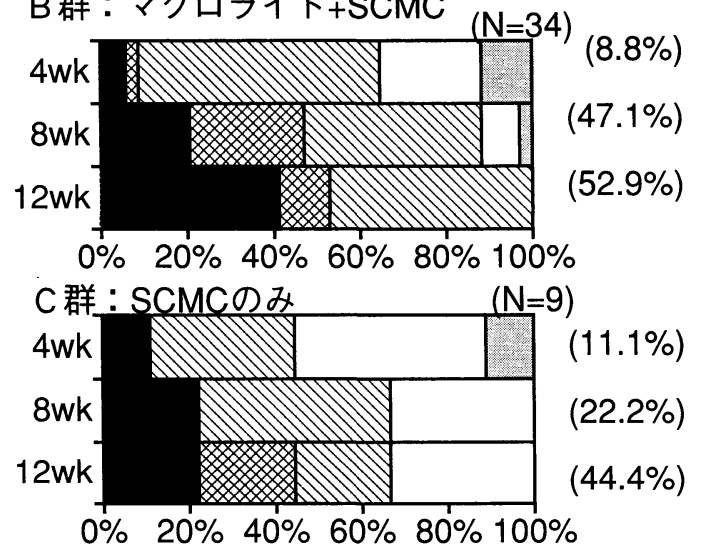

著効因有効 $₫$ やや有効 $\square$ 不変 $\square$ 悪化

図 8 成人の慢性副鼻腔炎 単独例に対する有効率

口. 成人に対する効果（図 10)

成人では 12 週間抗アレルギー剤のみを投与した症 例数はなかったので, E群のみで検討した。

小児に比して， 8 週で $75 \% ， 12$ 週で $100 \%$ と極めて 高い有効率を示し, カイ自乗検定で 8 週, 12 週ともに 小児に対して有意差を認めた。 $(\mathrm{P}<0.05)$ 。

図 11 は, 投与 4 週目で不変または悪化した症例のそ の後の治療効果を示したものであるが, 少数例を除い て小児, 成人ともに改善傾向を示し, 小児では 10 例中 4 例が, また成人では 3 例全てが 12 週で著効に移行し た。

\section{考察}

$\mathrm{EM}$ 少量長期投与の有効性がびまん性沉細気管支炎 に関して工藤ら ${ }^{8)}$ にり報告されて以来, 慢性副鼻腔 炎についても EMもしくはEM誘導体である RXM, CAM などの 14 員環系マクロライドの少量長
$\mathrm{D}$ 群 : 抗アレルギー剂のみ

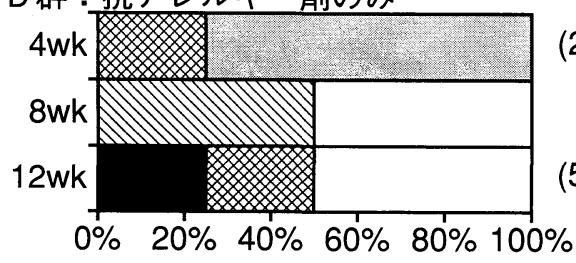

$(\mathrm{N}=4)$ $(25.0 \%)$

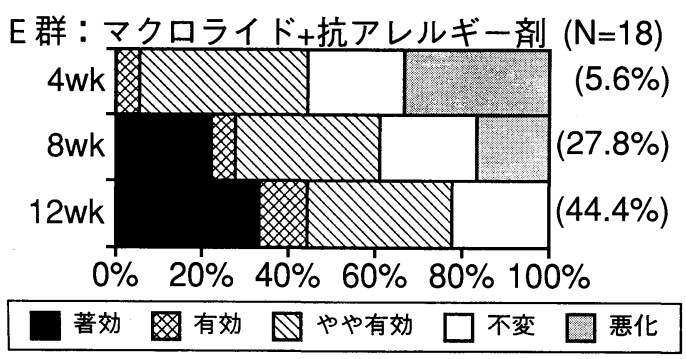

図 9 小児のアレルギー性鼻炎合併例に対する有 効率

$E$ 群：マクロライド+抗アレルギー剂 $(\mathrm{N}=8)$

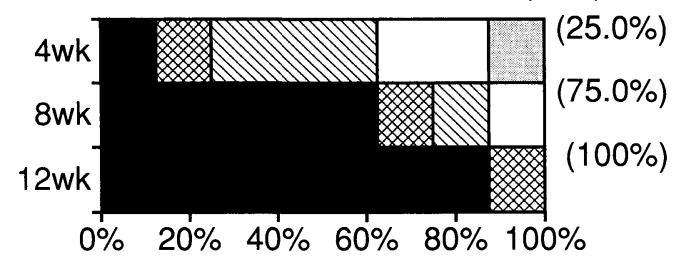

著効 有効 $\triangle$ やや有効 $\square$ 不変 $\square$ 悪化

図 10 成人のアレルギー性鼻炎合併例に対する 有効率

期投与療法の有効性が認められ, 治療として定着しつ つある感がする。

14 員環系マクロライドの作用機序としては，1）粘 液過㮃分泌の抑制 ${ }^{9}$ ，2）好中球の活性化 ${ }^{10)}$ ，3）リン

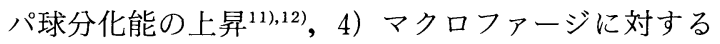
作用 ${ }^{13)}$ ，5）バイオフィルム産生の抑制 ${ }^{14)}$ などが報告 され，これらの作用を期待して慢性副鼻腔炎に対する マクロライドの少量長期投与療法が行われ, 多くの報

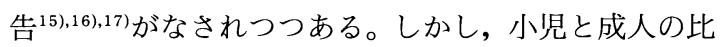
較や，投与期間についての検討は未だあまり多いとは いえず，今回，我々はこの点に関して検討を試みた。 
$\mathrm{E}$ 群：マクロライド+抗アレルギー剤
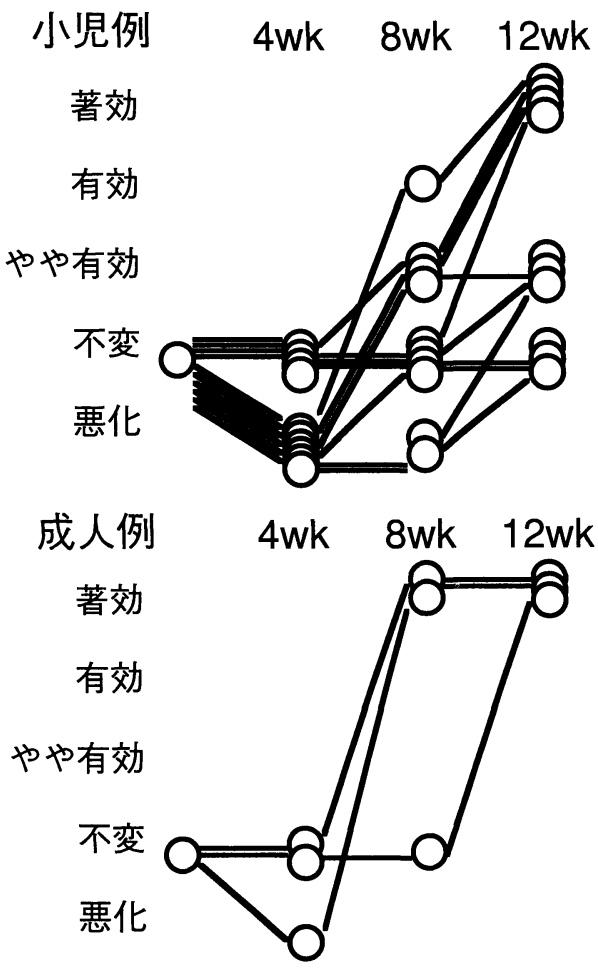

図 11 同一症例での効果の変化

洲崎ら ${ }^{4)}$ は, EM 少量長期投与で小児と成人を比較し て, 自覚症状, 他覚所見ともに成人の改善率が小児に 比して有意に高い結果を得，小児で改善率が低い理由 として，小児慢性副鼻腔炎は自然治癒率が高いという 反面，鼻腺が多く，アデノイドによる換気障害や分泌 排泄障害がおこりやすく，I 型アレルギーの合併が多 いことを挙げている。また，获ら ${ }^{6)}$ は, 小児でも低年齢 者ほど有効率が高く, 高学年になると有効率は低下し ていると報告している。我々の検討では, 小児, 成人 ともに有効率が高かったのは後鼻漏, 鼻閉, 鼻汁の順 であったがともに同程度の有効率を示し，小児と成人 で有意差は認められなかった。唯, 成人の鼻茸に対し ては著効, 有効例が認められたのに対し, 小児では, 症例数が少ないこともあるが, 効果は認められなかっ た。

アレルギー性鼻炎の合併は小児で $52 \%$, 成人で $25 \%$ の合併率であり，小児に高い合併率を認めた。これを
考慮して今回の検討ではアレルギー性鼻炎非合併例と 合併例に分け，且つ投与薬剤別に小児と成人の比較を 行ったが，単独例に関しては，小児のA群（マクロラ イドのみ)では 4，8，12 週目でそれぞれ 20\%，40\%， $60 \%$ の, B群(マクロライド+SCMC)では $20 \%, 45 \%$, 75\%の有効率であり，ともに週を追う毎に有効率は高 くなったが, 12 週投与時ではA・B群間に有意差を認 めなかった。

一方, 成人でも同様に週を追う毎に有効率は高く なったがA群 $60 \%$, B 群 $52.9 \%$ と両群間に有意差はな く, C群 (SCMC) でも $44.4 \%$ の有効率を示すことが わかった。

マクロライド単独のA群では小児, 成人ともに $60 \%$ の有効率で差はなかったが, 症例数が最も多かった $\mathrm{B}$ 群で比較してみると, 小児は $75 \%$, 成人は $52.9 \%$ と有 意差はみられないものの小児の方が高い有効率を示 し, 小児の単独例でマクロライドと SCMC 併用投与に 対する反応性が良いと考えられた。

一方, 成人では, 12 週投与で最高 $60 \%$ の有効率であ り，小児に比してやや反応性は弱いといえるが，12 週 以上の長期投与での効果については今後更に検討が必 要と思われる。

次に, 鼻ア合併例を $\mathrm{E}$ 群（マクロライド+抗アレル ギー剂）で比較してみると，小児では 8 週，12 週の有 効率が $27.8 \% ， 44.4 \%$ と低いのに対して, 成人では $75 \%, 100 \%$ と有意に高い有効率を示した。これは, 成 人の単独例の有効率が低かったのとは好対称であっ た。

また, 今回, 鼻ア合併例に対して, D群と $\mathrm{E}$ 群に分 けて比較を試みたのは，近年アレルギー性鼻炎を合併 した慢性副鼻腔炎の症例が増加していることを考慮し たからであるが,成人では 12 週間投与を続けた D群の 症例がなかったので, 抗アレルギー剤とマクロライド の単独効果や相乗効果については結論し得なかつ た。

また，小児における鼻ア合併例の薬剤に対する反応 性が 12 週投与ではなお低いことを示す結果であった が，これが小児のアレルギー性鼻炎合併例に対する治 療の限界なのか, あるいは更に長期投与すれば成人と 同程度の有効率が得られるか否かについては, 今後, より長期の投与を行って検討する必要がある。しかし， この点に関しては, 副作用, 臨床検査值異常の発生の

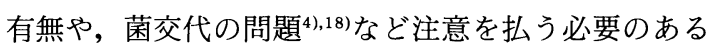


表 6 長期観察例の小览慢性副鼻腔炎の効果

\begin{tabular}{|c|c|c|}
\hline & $\begin{array}{c}\text { 副鼻腔炎単独 } \\
(\mathrm{N}=8)\end{array}$ & $\begin{array}{c}\text { アレルギー性鼻炎合併 } \\
(\mathrm{N}=18)\end{array}$ \\
\hline
\end{tabular}

治療効果

\begin{tabular}{|ll|l|c|}
\hline 改 & 善 & $5(63 \%)$ & $15(83 \%)$ \\
\hline 不 & 変 & $3(38 \%)$ & $2(11 \%)$ \\
\hline 判定不能 & 0 & 1 \\
\hline
\end{tabular}

投与期間

\begin{tabular}{|c|c|c|}
\hline 改 善 例 & 4 力月 & 8 力月 \\
\hline 不 変 例 & 13 力月 & 24 力月 \\
\hline
\end{tabular}

点が多々ある。しかし，図11に示す如く，投与初期に は薬剤に対する反応が無かったり，かえって悪化する 症例でも投与を継続していると改善傾向を示す症例が ある。我々はこの点に関して, 過去 2 年以上にわたつ て長期の治療および経過観察を行っている 26 例の小 児（15 歳以下）慢性副鼻腔炎症例について，その治療 結果を検討してみた(表 6 )。判定基準は自覚症状と他 覚所見およびX線所見により，臨床症状の評価および $\mathrm{X}$ 線所見の効果判定の項で述べたのと同様の判定規準 に準拠している。

これらの症例の平均年齢は 6.8 歳で, 投与したマク ロライドは EM と CAM であり, 常用量の $1 / 2$ の投与 量を，また鼻ア合併例に併用投与した抗アレルギー剤 は常用量を投与している。慢性副鼻腔炎単独の 8 症例 では $63 \%$ が改善し，その際の平均投与期間は 4 力月で あった。すなわち，先に述べた 12 週投与の有効率とほ ほ同様の改善率であり，小児の単独例に対するマクロ ライドの治療は 12 週投与でも 4 力月投与でも約 $60 \%$ の有効率ないし改善率ということができるのではない かと考えられる。一方, アレルギー性鼻炎合併例では, 18 例中 15 例 (83\%) が改善しているが，この改善に要 した平均投与期間は 8 カ月であった。

限られた少数例なので, 結論づけることは勿論でき ないが, 12 週では有効率が低かった小児アレルギー性 鼻炎合併の慢性副鼻腔炎でも 8 力月という長期の投与 では, より高い効果が得られることを示唆するものと 思われる。

慢性副鼻腔炎に対するマクロライドの少量長期投与 の有用性について言及された報告は多いが，長期投与
による副作用の問題，再発例の対応，マクロライド無 効例の検討, アレルギー性鼻炎合併例に対する抗アレ ルギー剤併用の問題など今後なお多くの点について検 討する必要があると思われる。

\section{ま と め}

1. 問診および諸検査により慢性副鼻腔炎と診断し た小児（ 4 歳～15 歳） 71 例と成人（16 歳以上） 87 症 例について, 単独例と鼻ア合併例に分けて, 14 員環系 マクロライドの少量長期投与の効果を比較, 検討した。

単独例についてはA 群（マクロライド単独投与群), $\mathrm{B}$ 群（マクロライドと SCMC 併用投与群), C 群 (SCMC 単独投与群) の 3 群に分けて効果を検討し, 鼻 ア合併例については，D群（抗アレルギー剤単独投与 群）と $\mathrm{E}$ 群（マクロライドと抗アレルギー剤の併用投 与群）の 2 群に分けて効果を検討した。

2. 自覚症状，他覚所見に関しては，小児と成人て マクロライドの効果に有意差を認める項目はなく，と もにほほ同様の有効率であった。

3.X線所見の改善率は単独例では，小児は $42 \%$, 成人で $21 \%$ ，鼻ア合併例では小児 $50 \%$ ，成人 $80 \%$ て あった。

4. 単独例では，小児の最終投与時の有効率は $\mathrm{A}$ 群 $60 \%$, B 群 $75.0 \%$ であり, 成人では $\mathrm{A}$ 群 $60 \%$, B 群 $52.9 \%$, C群 $44.4 \%$ であった。小児と成人で各群とも に有意差は認めなかった。なお, 小児では 12 週間投与 を行ったC 群の症例はなかった。

5. 鼻ア合併例では,小児の 12 週投与時の有効率は D群 50\%, E群 $44.4 \%$ であったが, 成人では $100 \%$ で あり，小児に比して有意に高い有効率を示した。

6. 小児慢性副鼻腔炎に対して少量長期投与療法を 2 年間以上行っている 26 例の検討では, 単独例 ( 8 例) では平均 4 カ月のマクロライド単独投与で $63 \%$ の改 善率であったが, 鼻ア合併例（18 例）では平均 8 力月 のマクロライドと抗アレルギー剤の併用投与で $83 \%$ の改善率であった。小児鼻ア合併例では 12 週間の投薬 では効果はなお不十分で，より長期の投与で改善率は なお高くなることが期待された。

7. 明らかな副作用は認めなかった。

本論文の要旨は第 34 回日本鼻科学会学術講演会シ ンポジウム「小児および成人における鼻副鼻腔炎の病 態とその治療」において講演した。 


\section{参考文 献}

1）夜陣紘治, 原田康夫, 杉本嘉朗, 他: 慢性副鼻腔 炎の有病率について。耳鼻臨床 74: 2082-2095, 1981.

2）竹野幸夫, 夜陣紘治: 小児慢性副鼻腔炎の疫学的 変遷と病態の変化. 小児耳鼻咽喉科 $16: 1996$. 投稿中

3）飯沼壽孝, 夜陣紘治: 高齢者の副鼻腔炎の取り扱 い. 日耳鼻 97:2044-2048, 1994.

4）洲崎春海, 菊地 茂: 慢性副鼻腔炎一エリスロマ イシンの少量長期投与療法一. JOHNS 8： 1603-1608, 1992.

5) 羽柴基之, 宮本直哉, 木村利男, 他: 慢性副鼻腔 炎に対するエリスロマイシン誘導体（クラリスロ マイシン) の効果. 日鼻誌 $31: 269-280,1992$.

6）获 良博, 川口隆明: 小览鼻副鼻腔炎に対する EM 少量投与法. 耳鼻臨床 86：603-308，1993.

7）増田佐和子, 間島雄一, 平田圭甫, 他：L-シス テインの慢性副鼻腔炎に対する効果. 耳鼻臨床 82: 625-633, 1989.

8）工藤翔二, 木村 仁, 植竹健司, 他: びまん性汎 細気管支炎にたいするマクロライド系抗生剤の少 量長期投与の臨床効果. 日胸疾会誌 22 (増): 254, 1984 .

9) Goswami SK, Kivity S, Marom Z:Erythromycin inhibits respiratory glycoconjugate secretion from human airways in vitro. Am Rev Respir Dis 141: 72-78, 1990.

10）諏訪義章, 八鍬 直, 中村秀範, 他：いわゆるび まん性沉細気管支炎に対するエリスロマイシン少 量長期投与療法一投与前後の末梢血白血球機能の 検討一. 日胸疾会誌 $26: 1284-1290,1988$.

11) Van Rensburg CEJ, Anderson A, Joone G, et al :
Effect of erythromycin on cellular and humoral immune functions in vitro and in vivo. $\mathrm{J}$ Antimicrob Chemother 8: 467-474, 1981.

12) Anderson R. Van Rensburg CEJ and Eftychis H. : Further studies on erythromycin effects on cellular immue functions in vitro and in vivo; enhancement of neutrophil motility by erythromycin combined with ascorbate or thiamine. J Antimicrob Chemother 10: 409-417, 1982.

13）片平潤一, 清水喜八郎: エリスロマイシンはなぜ 効くのか 5 . マクロファージ単球系への作用, エリスロマイシンなど 14 員環系マクロライド剤 のマクロファージ系前駆細胞増殖刺激作用. Therapeutic Res 11: 561-563, 1990.

14）武田博明, 大垣憲隆, 菊地直美, 他: びまん性汎 細気管支炎に対するマクロライド作用の検討一緑 膿菌 biofilmに対するクラリスロマイシンの影響 一. 感染症学雑誌 $66: 1454-1461,1992$.

15）菊地 茂, 洲崎春海, 青木彰彦, 他: 副鼻腔炎と エリスロマイシン少量長期投与. 耳鼻臨床 84 : 41-47, 1991.

16）菊地 茂, 山岨達也, 洲崎春海, 他: 副鼻腔炎と エリスロマイシン少量長期投与一第 2 報一. 耳鼻 臨床 85: 1245-1252, 1992 .

17）高北晋一, 北村溥之, 大八木章博, 他：慢性副鼻 腔炎と少量エリスロマイシン療法. 耳鼻臨床 84: 489-498, 1991.

18）木村貴昭, 保富宗城, 山中 昇: EM 少量長期投 与に打ける菌交代について. 日耳鼻感染症研究会 誌 $12: 5-8,1994$.

(1995 年 12 月 25 日受稿, 1996 年 1 月 17 日受理) 